\title{
Sending carmelites to Portuguese America in 1580: the letter from Friar João Cayado as a guideline for action
}

\author{
André Cabral Honor[1]
}

\begin{abstract}
Starting with the narrative of the expeditions to conquer Paraíba River, this article attempts to understand the role assigned to the four carmelite friars who boarded in the fleet of Frutuoso Barbosa in 1580. These religious men carried a letter written by Friar João Cayado, the superior of the Portuguese Carmelite Province, which established the first operational guidelines for the Calced Carmelite missionaries travelling to Portuguese territories, besides delegating the necessary powers to the friars for the consolidation of the Order of Our Lady of Mount Carmel in America. Based on these indications, the friars metamorphosed the way they worked, adapting to the local demands by taking the opportunities that arose. Despite the adjustments, the main goal of the work of these religious men in Brazil, which was to meet the spiritual demands of natives and the ordinary population, did not change. The same guideline that directed the carmelites to America was also responsible for the decay of the Order and its near extinction in Brazil in the 19th century.
\end{abstract}

Keywords: carmelites; catechizing; Paraíba.

\section{O envio dos carmelitas à América portuguesa em 1580: a carta de Frei João Cayado como diretriz de atuação}

\section{Resumo}

Iniciando com a narrativa das expedições de conquista do Rio Paraíba, o presente artigo tenta compreender o papel que foi designado aos quatro frades carmelitas que embarcaram na armada de Frutuoso Barbosa em 1580. Esses religiosos carregavam uma carta escrita por Frei João Cayado, provincial da Província Carmelita Portuguesa, a qual estabelecia as primeiras diretrizes de atuação dos missionários carmelitas calçados em terras portuguesas, além de delegar os poderes necessários aos frades para a consolidação da Ordem de Nossa Senhora do Carmo na América. Baseando-se nessas indicações, os frades metamorfosearam a maneira como atuavam, adaptando-se às demandas locais por meio do aproveitamento das oportunidades que surgiam. Apesar dessas adequações, o objetivo principal da atuação desses religiosos no Brasil não se modificou: atender às demandas espirituais de indígenas e população ordinária. A mesma diretriz que moveu os carmelitas para a América também foi a responsável pela decadência da Ordem e sua quase extinção no Brasil no século XIX. Palavras-chave: carmelitas; catequização; Paraíba.

\section{El envío de los carmelitas a la América portuguesa en 1580: la carta de Fray Juan Cayado como una instrucción para la acción}

\section{Resumen}

A partir de la historia de las expediciones de conquista del Río Paraíba, este artículo intenta comprender el rol que se les asignó a los cuatro frailes carmelitas que abordaron la armada de Fructuoso Barbosa en 1580. Estos religiosos llevaban una carta escrita por el Fraile João Cayado, provincial de la Provincia Carmelitana Portuguesa, que estableció las primeras instrucciones operativas a los misioneros carmelitas calzados en tierras portuguesas y delegaba a los frailes las facultades necesarias para la consolidación de la Orden de Nuestra Señora del Monte Carmelo en América. En base a estas indicaciones, los frailes metamorfosearon la manera en que actuaban, adaptándose a las necesidades locales mediante el uso de las oportunidades que se presentaron. A pesar de estos ajustes, el objetivo principal de la actuación de los religiosos en el Brasil no ha cambiado: satisfacer las demandas espirituales de los pueblos indígenas y de la populación común. La misma orientación que trasladó a los carmelitas a la América fue también la responsable por la decadencia de la Orden y su casi extinción en Brasil del siglo 19.

Palabras clave: carmelitas; la catequesis; Paraíba.

\section{L'envoi des carmélites à l'Amérique portugaise en 1580: la lettre du Frère João Cayado comme ligne directrices}

\section{Résumé}

En commeçant avec la narrative des expeditions de conquête de la rivière Paraíba, cet article essaie de comprendre le rôle de les quatre frères carmélites qui ont embarqué avec l'escadrile de Frutuoso Barbosa en 1580. Ces religieux portaient une lettre écrite par le Frère João Cayado, provincial de la Province Carmélite Portugaise, en fixant les premières lignes directrices pour lactuation des missionaires carmèlites en terre portugaise et en délèguant des pouvoirs aux frères pour consolider l'Ordre de Notre Dame du Mont Carmel dans l'Amérique. Sur cette base, les frères ont changé leur strategies et actions, en sadaptant aux demandes à mesure que les opportunités surgissaient. En dépit des ajustements, leur objectif principal au Brésil na pas changé: rencontrer les demandes spirituelles des indigènes et de la population. Ces directrices ont également été responsables pour la decadence et la quasi-extinction de l'Ordre au Brésil dans le XIXe siècle.

Mots-clés: les carmélites; catéchisme; Paraíba. 
he first attempt to conquer the Paraíba River was indeed disastrous. In 1574, D. Luiz de Brito Almeida, who at the time was the governor-general, ordered D. Fernão da Silva, general magistrate and chief provider of the State Treasury, to go out on an expedition toward the river. On horseback, he had a small troop, constituted by Portuguese men and Indian allies, which followed him on foot. The fleet set off in search of the Potiguaras in order to punish them for their bellicose behavior toward the settlers. The attack was doomed, and the survivors had to flee through the sandy part of the beach, where they were closely pursued by the natives. ${ }^{1}$

The relationship with potiguaras had been friendly before. With the help of these autochthons, the Portuguese managed to defeat the caetés, a group that inhabited the coast of the Captaincy of Pernambuco when the first ships coming from Portugal docked there. The potiguaras took advantage of the arrival of the Portuguese and of the Lusitanian interest in the lands of Capibaribe and Beberibe rivers to destroy their historical enemies, the caetés. The indigenes were, at the same time, the barrier to be defeated for the occupation of the territory and part of the solution to overcome this obstacle, participating in the wars that cleared warlike natives out of the way. If not killed in combat, they could be part of the colonization as slaves.

The potiguaras inhabited the lands around the river of bad waters, which is the meaning of "Paraíba" in Tupi, ${ }^{2}$ and also dominated the Serra da Copaoba, as the current Serra da Borborema used to be called. The river banks formed a safe haven for the natives. Besides being a strategic area for the defense against external and internal intruders, this was also a place where the indigenes negotiated the "pau de tinta" - also known as "pao Brazil" — with French pirates with whom they had a profitable exchange.

The economic base that stimulated the exports in the 16th century was constituted by the extraction of wood with ember-color core and the production of sugar by importing and adapting Asian sugarcane to the region's soil. The establishment of a mill was an expensive enterprise and demanded a good investment. A reasonable amount of arable land fit for planting sugarcane was required. Moreover, it was necessary to produce subsistence items that could be used in the daily supply to the mill.

Diogo Dias was one of those men who decided to become a plantation owner in Portuguese America. Described by historiography as a rich man, it is not known if his richness came from commerce or agriculture. Regardless of the source of his possessions, what matters at the moment is to know his

\footnotetext{
'The expeditions to conquer the lands of Paraíba River are described in Sumário das Armadas, an anonymously authored document, written between 1585 and 1587. A more detailed analysis of this document can be found at: Adriel Fontenele Batista. O Sumário das Armadas: guerras, visão e estratégias discursivas na conquista da Paraíba, Dissertação de mestrado, Universidade Federal do Rio Grande do Norte, Natal, 2012. Available from: <http://repositorio.ufrn.br:8080/jspui/bitstream/1/8784/1/AdrielFB_DISSERT pdf>. Accessed on: July 10, 2013. For an analysis of the five expeditions to conquer Paraíba River, associating them with the need to expand the sugar production of the Captaincy of Pernambuco, see: Regina Célia Gonçalves, Guerras e açúcares: política e economia na capitania da Paraíba, 1585-1630, Bauru, Edusc, 2007.

${ }^{2}$ The Indians called the river "Paraíba" because of the constant agitation of its waters, which prevented them from navigating it with their canoes.
} 
ultimate project: a mill on the banks of Goiana River, also called CapibaribeMirim, where he "was able to not only plant cane fields and build houses and sugar mills but also erect a fortress and a palisade for the defense of his lands". He gathered Indians to work on the property and settled there with his family and some other settlers. The settlement of these lands represented the expansion of the sugar farming occupation to territories located on the border of Potiguara domains. The rapid depletion of some coastal areas and the constant need to increase production made the lands of Capibaribe-Mirim River essential to maintain the continued expansion of the Captaincy of Pernambuco's cane sugar crop, as the manufacture and trade of sugar were booming, which required the expansion of plantation areas.

The building of a mill on the banks of the Goiana River, or Capibaribe-Mirim, on the border with potiguaras in the early seventies meant an important step toward the permanent occupation of the area by the Portuguese, even because Diogo Dias' initiative stimulated other residents of Itamaracá and Pernambuco to do the same. ${ }^{4}$

With the invasion of the lands of Capibaribe-Mirim River, the tenuous truce between Portuguese and potiguaras was broken. The next logical step was to continue the expansion of farming to the Paraíba River region.

The fight for territories was at the core of the indigenous culture; thus, the invasion of their lands was interpreted as a declaration of war by the potiguaras. Moreover, in the 16th century, the mills used mostly indigenous labor. Therefore, to convert the land of the potiguaras into sugarcane plantations also meant transforming the Indians into workers of the sugar units, whether by slavery or provision of services. In other words, the indigenous element was a crucial factor that interfered directly in the success of the colonization of Portuguese America.

The reaction to the building of Diogo Dias' mill came in 1574, when the potiguaras promoted a massacre after they invaded and destroyed Tracunhaém Mill. In 1575, the Governor D. Luiz Brito de Almeida assembled a small army in Salvador to conquer the river of bad waters himself. He equipped a fleet and sailed on a ship that would return to Bahia without ever reaching the lands of Paraíba River. The bad winds forced the governor and his crew to return to where they came from.

A new expedition would be organized only in 1579. Problems, such as the high cost of the fleet headed by D. Luiz and the issue of Portuguese succession, which would get the attention of Portugal after the death of King D. Sebastião I at the Battle of Alcácer-Quibir in 1578, explain the postponement of the conquest of Paraíba River. Meanwhile, the situation only became worse for the Portuguese. The successive indigenous attacks virtually emptied the Captaincy of Itamaracá,

${ }^{3}$ Regina Célia Gonçalves, Guerras e açúcares: política e economia na capitania da Paraíba, 1585-1630, Bauru, Edusc, 2007, p. 69.

${ }^{4} /$ bidem, p. 68. 
and the entire population was forced to take refuge in Itamaracá Island, while the potiguaras were close to the limits of the Captaincy of Pernambuco, threatening the Portuguese settlement in the region. The process of occupation of the territory in the northern captaincies of the State of Brazil was in peril, and the Portuguese were at risk of losing their land and the money invested in the region.

The advance of potiguaras on the sugar-farming areas of the captaincy of Pernambuco clearly indicated that the occupation of American land by the Portuguese could only materialize with the subjugation of the indigenous people.

Alarmed by the grave news that came from the northern captaincies, Cardinal D. Henrique, the king of Portugal then, authorized the formation of a new fleet to conquer Paraíba River and to end the Potiguara threat. Without resources to finance the venture, the solution he found was to establish a partnership with an individual who was interested in the exploitation of those lands, promising him the position of captain of that territory for ten years after its conquest.

I, the King, communicate to those who see this license that I am sending now Fructuoso Barbosa to populate the lands of Paraíba in the areas of Brazil and remove the pirates that are there now and have occupied them. He is taking with him some residents of this kingdom to live there, so I have decided that Fructuoso Barbosa shall be the captain of that entire people, starting from the ones navigating with him on the trip at sea. After he reaches the mentioned lands and stays on them for as long as he pleases, I have decided that he shall also be the captain of the fortress and town that he will organize in these lands. This is valid for ten years, unless I order otherwise. ${ }^{5}$

As it is explained in the document, Frutuoso Barbosa came with the intent to conquer and populate the lands of Paraíba River. For this to be accomplished, he brought along some residents, among which were four Carmelite friars. ${ }^{6}$ Those were the first religious men of the Order of Our Lady of Mount Carmel to go to Portuguese America.

It was the manager of the Order, Friar João Cayado, who authorized the participation of the religious men in the fleet organized by Frutuoso Barbosa. The letter ordering the four Carmelite friars to be sent to Portuguese America was originally written in Latin and until today cannot be found in archives. Its content is only known today because, in the early 18th century, Friar Manoel de Sá opted to include its complete translation in the chronicle he was writing about the Order of Our Lady of Mount Carmel. The letter is a type of birth certificate of the missionary project of Carmel in Lusitanian lands.

\footnotetext{
${ }^{5}$ Cônego Florentino Barbosa, "Documentos Históricos", Revista do Instituto Histórico e Geográfico Paraibano, vol. 10, João Pessoa, 1946, p. 173-174.

6 In 1593, the Order of Our Lady of Mount Carmel was divided into two: the Discalced, a result of the Teresian reform promoted by Saint Teresa of Jesus in the 16th century, and the Calced, founded in the late 11th century and that, from the 17thcentury on, would have two different constitutions: the Ancient Observance and the Strict Observance, with the latter originating from the Turonic Reform in the 17th century. On this subject, see: André Cabral Honor, Universo cultural carmelita no além-mar: formação e atuação dos carmelitas reformados nas capitanias do norte do Estado do Brasil (sécs. XVI a XVIII), Tese de doutorado, Universidade Federal de Minas Gerais, Belo Horizonte, 2013; Maria das Graças Souza Aires Araújo, Carmelitas em Pernambuco: fixação e expansão, Dissertação de mestrado, Universidade Federal de Pernambuco, Recife, 2000.
} 
Master Friar João Cayado, Provincial Vicar of the Order of Our Lady of Mount Carmel, in this Kingdom of Portugal, because it is our duty, and of all the religious men who profess our way of life, to serve God and his Blessed Mother, dedicating ourselves carefully to the salvation of souls and to the spread of the Christian Religion. We see that this will please very much the Lord Himself, that we should be useful as professors of the true Faith to the ones who are devoid of its light, living in the areas of Brazil and that do not have priests to instruct them about the precepts of Christ. Others will administer the Sacrament of Penance, imbued with the Charity to the neighbor, with the obligation of our craft and with the homage we must pay to our very Christian King Dom Henrique, who is very pleased with the extension of our name in the areas of Brazil, as he has said to us. He asked his illustrious Captain Fructuoso Barbosa to solicit carefully if we could come in his company, as he has done with much affection. We sent the very religious fathers Friar Domingos Freyre, Friar Alberto, Friar Bernardo Pimentel, and Friar Antônio Pinheyro, all men of proven religion, professed priests of our Order, to accompany the mentioned captain, in the trip that is to be done to build the City of Parahiba, where they can found a monastery of this Order, that will be named Our Lady of Victory, and not only on this land, but also in Pernambuco, and in all those places offered to them, if convenient to the service of God, and to the souls of the neighbors, and to the benefit of religion. In such regions, Father Friar Domingos Freyre will preach the Gospel of Christ, and hear confession, and his other fellow priests, if approved by the Most Reverend Ordinary of the place, will perform the other crafts of priests and religious. We name the Father Domingos Freyre Vicar, to whom they own obedience and respect as to their Prelate, and to whom we transfer our opportunities and powers, and give the responsibility of caring for the mentioned religious, in the temporal and spiritual spheres. They may, by commission of our Most Reverend General Master João Baptista de Ravenna, welcome to our Brotherhood all those who, with piety and devotion, ask to join, and give the brothers the letters granted by Pope Clemente VII, and confirmed by Pope Gregorio XIII. They will not only do this, but everything else that we would do if we were present, always following the orders of the Reverend Father Prior of our Convent in Lisbon, to whom they will resolutely obey, unless the Provincial section determines otherwise. We ask, with all the submission and charity owed to brothers, the Most Reverend Bishop of Brazil, and his Cures and Vicars, to receive the mentioned fathers with the kindness and charity characteristic of their work, and to make use of their ministry and laboriousness for the health of the souls. Thus, they will not only achieve a great prize of charity, from what they give to all their people, but also to these four. Given in this Convent of Lisbon under our sign and with the stamp of our Office on January 26, 1580. M. Friar João Cayado. ${ }^{7}$

\footnotetext{
"Frei Manoel de Sá, Memórias históricas da Ordem de Nossa Senhora do Carmo da Provincia de Portugal, Lisboa Oriental, Offycina Josep. Antonio da Silva, 1727, p. 33-35. Written in two volumes, the second part of the chronicle of Friar Manoel de Sá was lost in 1755, when the great Lisbon earthquake, followed by a tsunami, completely destroyed the carmelite convent of the city and its precious archive. As Manoel de Sá reveals in the preface of the first volume, the second volume was about the carmelite presence overseas.
} 
Aware of the role that the missionaries had in the consolidation of colonization, especially in dealing with the natives, Frutuoso Barbosa, as future master of the lands of Paraíba River, gave the carmelites the right to establish the first convent in the city to be built, which should be consecrated to Our Lady of Victory. Thus, the religious monument would also serve as a landmark of the conquest of Paraíba River and the consequent defeat of the natives, in addition to promoting the worship of the "Holy Mother" ${ }^{8}$ of God in Lusitanian lands. The reference to the convent suggested the fate of potiguaras: their defeat in a fair war, which would lead to the extermination or enslavement of these indigenes.

\section{The potiguaras took advantage of the arrival of the Portuguese and of the Lusitanian interest in the lands of Capibaribe and Beberibe rivers to destroy their historical enemies, the caetés}

Friar João Cayado explains that the regular clergy had the obligation to expand the Christian faith throughout the world and that, at the request of the Portuguese King, the carmelites should also catechize people in the areas of Brazil. The friars of the Order of Our Lady of Mount Carmel added specificity to their motivations. Besides having the obligation to serve God, which is the main reason that drives any member of the regular clergy, they should serve Our Lady, matron of the Order. In the Captaincies of Paraíba $(\mathrm{CPb})$ and Pernambuco (CPe), the churches founded by the carmelites had predominantly Marian invocations: Our Lady of Mount Carmel (City of Paraíba, CPb; Recife, Cape of Santo Agostinho; and Hospice of Arraial, CPe), Our Lady of the Exile (Olinda, $\mathrm{CPe}$ /Discalced carmelites), Our Lady of Guidance (Hospice of Lucena, Cpb), Our Lady of Mercy (Hospice of Mercy, CPe), Our Lady of Light (Hospice of Japomim, $\mathrm{CPe}$ ), and Our Lady of Conception (Hospice of Jiqui, CPe). The exceptions are the Church of the First Carmelite Order of Goiana (Captaincy of Itamaracá), which invokes Saint Alberto, and the Carmelite Church of the First Order of Olinda (CPe), which invokes Saint Antônio.

In the letter from Friar João Cayado, America's population is divided into two groups: the defaulters of the "true faith", a reference to the natives black men of the land, and the ones already Christianized that needed spiritual guides to preserve Christianity.

Although they had not yet reached the Portuguese America, the translation process between indigenes and missionaries had already begun, because the news of the contact circulated in Europe.

${ }^{8}$ All quotes without reference allude to the transcribed letter of Friar João Cayado. 
The works of evangelization and learning Christianity were a continuous movement of rapid change and incessant increases in symbolic systems, from one side and the other, so they could continue to make sense in a world that was no longer the same as the one where those systems were formed. In the indigenous side, there was never passive acceptance and indiscriminate absorption of the faith imposed by the missionaries, nor there was a phenomenon of "resistance", understood as a total refusal of catechesis, and affirmation of their traditional customs, or a "return" to them. What happened was a process of negotiation or, to say it better, of "translation". What happened was the choosing of strategies to solve the problem, linguistic and cultural, of recognizing in the "other" elements that could be reducible to the cultural world of "I".

The dissemination of this knowledge gave people that had never had contact with the American natives, as Friar João Cayado, a Europeanized vision of the indigenes that modified as the contact progressed. "The extraordinary coincidence of these observations, it is worth recalling, depends less of a coincidence of observed facts than of the dissemination of reports among the writers." ${ }^{10}$ The idea of a people that "have no faith, nor law, nor King"11 was already discarded by the carmelites when they spoke of the need for "professors of the true Faith to the ones that were devoid of its light, living in the areas of Brazil and that do not have priests to instruct them about the precepts of Christ [...].

The informative idea is the adage of Cicero, used by the scholastics, that there are no people, no matter how barbaric, that do not have in themselves a minimal notion of deity. The points of departure and arrival coincide: the religion, the belief, is a universal fact. The problem is to transform the "belief" into the true Faith, while turning the "barbarism" into civilization. ${ }^{12}$

The news about the Jesuit experience with the indigenes are fundamental in the construction of the thought of Friar João Cayado, who ignores the information presented by the first chroniclers, delivering a posterior vision, resultant of the translation process that occurred between missionaries and natives, which attributed some notion of faith to the indigenes.

The recently sent Carmelite religious also had the assignment to evangelize the Portuguese population living in towns and cities, establishing Catholicism as the basis of identification between the Portuguese director center and the American territory. For this purpose, they would establish themselves in temples,

\footnotetext{
9Maria Cristina Pompa, Religião como tradução: missionários, Tupi e "Tapuia” no Brasil colonial. Tese de doutorado, Universidade Estadual de Campinas, Campinas, 2001, p. 90. Available from: <http://www. bibliotecadigital.unicamp.br/document/?code=vtlsO00220275>. Accessed on: September 6, 2014. $10 /$ bidem, p. 28.

"Pero de Magalhães de Gândavo, A primeira história do Brasil: história da província de Santa Cruz a que vulgarmente chamamos Brasil, Rio de Janeiro, Jorge Zahar, 2004, p. 135.

12Paula Montero (org.), Deus na aldeia: missionários, índios e mediação cultural, São Paulo, Globo, 2006, p. 117.
} 
generally in the higher parts of towns and cities, where they celebrated masses, administered sacraments, and held celebrations and processions that attracted the faithful to the devotion to characters and elements of the historical culture of that Order. ${ }^{13}$

To profess a religion could even be an easy task. The difficult thing was to maintain the Christian conduct in everyday life. To restrain sin and the devil's influence, the Council of Trent recommended the sacrament of penance.

\begin{abstract}
If in all the regenerated men there was such gratitude to God so they would constantly maintain the justice received in baptism for their benefit and grace, another sacrament instituted for the remission of sins other than this [can. 2] would not be necessary. But as "God who is rich in mercy" [Eph 2.4] "knew the fragility of our origin" [Ps 103.14], He also wanted to grant a life-giving medicine to those who surrendered again to the bondage of sin and the power of the devil, namely the sacrament of penance [can. 1], by which one applies the benefit of Christ's death to those who fall after baptism. ${ }^{14}$
\end{abstract}

In line with the Tridentine precepts, when it came to maintaining the faith and deterring misconduct, the Carmelite friars should "administer the Sacrament of Penance", which, according to the 14th session of the Council of Trent, dated November 25, 1551, ${ }^{15}$ consisted of three stages: contrition (pain of the guilt for committing sin), confession (report of the impious act to a priest), and satisfaction (designated penalty). The purging of sins could only be completed after a "punishment", which should be well proportioned to serve as a lesson to the penitent, thus restoring his bond with Christ.

\footnotetext{
${ }^{13}$ t is understood as historical culture the accumulation of materials, physical and mental, produced and accumulated by mankind over time, differentiating itself, but, at the same time, mingling with the historiographical culture. "Finally, the concept of Historical Culture that, unless we want to be emphatic, is circular and redundant in its substantiation and its adjectives: all Culture is historical, and everything historic is also cultural. [...] Understood as a set of production and reproduction of human existence, Culture fits, therefore, in two dimensions without which it does not take place: time and space. And it is not accomplished, obviously, without an agent: Man, in society, whose capacity of reflexive imagination (instead of reflected) enables the mediation with nature, producing the second nature (Marx), or the cultured nature, which, in turn, produces the man. In this process, culture is made as a 'multiform palimpsest', in the words of Carlos Antonio Aguirre Rojas, because it includes adaptive, cognitive and symbolic systems; implies the production of material and symbolic artifacts; involves multiple agents; covers the production, circulation, transmission and reception of knowledge and human acts; requires socialization processes for the transmission of traditions and creative elaborations. In short: it is the set of experiences lived by Humanity and the meanings that human beings give to the world. Thus, the Historical Culture guards double meaning: one, generic, while produced by the History-process; another, more specific, such as History-knowledge, which would be better named, perhaps, as Historiographical Culture. Therefore, all Historical Culture contains a Historiographical Culture, the latter understood as a set of the representations formulated about the experiences of societies, social groups, people, in a perspective of temporality". Rosa Maria Godoy Silveira, "A cultura histórica em representações sobre territorialidade", Revista de História Saeculum, n. 16, João Pessoa, 2007, p. 42.

${ }^{14}$ Heinrich Dezinger, Compêndio dos símbolos, definições e declarações de fé e moral, São Paulo, Paulinas; Loyola, 2007, p. 426-427.

${ }^{15}$ The complete text of "Doutrina sobre o sacramento da penitência" can be found in: Ibidem, p. 426-436.
} 
But, in a curious parallel to the occupation of territory, soon it was realized that the simple mark of a conquest/conversion, in its representation of the process of Christianization, created more problems than solved. To tackle these problems, it was necessary to introduce the confession, instead of baptism, as the true gateway to Christianity. [...] And the new punishment - of a catechesis aimed at correcting by offering an adequate awareness of the duties, moral and civil, of the (new) Christian - emerged as the essential tool to convert not only the American wild populations but also masses of "infidels" and illiterate peasants that were being discovered, each time with greater concern, within Christian Europe itself. ${ }^{16}$

The problems faced in converting the autochthonous Americans through baptism reflected in the modus operandi of the missions in Europe, which, in turn, influenced the actions of the regular clergy within the so-called Christian population of the Americas. The sacrament of Penance was emphasized as an instrument to maintain faith. This did not diminish the importance of baptism, because, according to the Council of Trent, "the Church does not exercise jurisdiction over a person who has not entered first through the gate of baptism". ${ }^{17}$

\section{The fight for territories was at the core of indigenous culture; thus, the invasion of their lands was interpreted as a declaration of war by potiguaras}

In the context of overseas expansion, the Catholic religion created a bond between Portugal and America. The friars were at the service of the king, as Friar João Cayado explains, "imbued with the Charity to the neighbor, with the obligation of our craft and with the homage we must pay to our very Christian King Dom Henrique". The institution of orders united the Portuguese State and the Catholic Church overseas.

The Portuguese orders can be broadly defined as a combination of rights, privileges and duties granted by the papacy to the Crown of Portugal as the patroness of the missions and Roman Catholic ecclesiastical institutions in vast regions of Africa, Asia and Brazil. ${ }^{18}$

${ }^{16}$ Adone Agnolin, Jesuitas e selvagens: a negociação da fé no encontro catequético-ritual americano-tupi (séculos XVI-XVIII), São Paulo, Humanitas, 2007, p. 25.

${ }^{17}$ Heinrich Dezinger, Compêndio dos símbolos, definições e declarações de fé e moral, São Paulo, Paulinas; Loyola, 2007, p. 428

${ }^{18}$ Charles R. Boxer, O império marítimo português: 1415-1825, São Paulo, Companhia das Letras, 2002, p. 243 
With the lifelong title of Master of the Order of Christ, the Portuguese King was responsible for collecting the church tithes, while overseeing the expansion of the Church in America, Asia, and Africa. The necessity to promote Catholicism in Portuguese America aimed at assuring the application of a European rule of conduct with the specific purpose to submit everyone to the Portuguese social order. By converting the population to Catholicism, the link that supported the authority of the Portuguese monarch in lands so distant was established. Thus, since the early days of the effective colonization of America, it was intended to incorporate into the Portuguese kingdom these young local elites, who, in turn, began to act according to the European ideals of life and nobility, even when they did not have these attributes from birth. "The power had the magical gift of purifying the blood and changing the color of the skin." ${ }^{19}$

\section{By converting this population to Catholicism, the link that supported the authority of the Portuguese monarch in lands so distant was established}

In this civilizing process, the carmelites emphasized the worship of Our Lady of Mount Carmel, establishing an identification that brought the inhabitants of Brazil closer not only to Portugal but also to the Carmelite Order. It was through the Carmelite historic culture that the friars of Carmel shaped the link that associated America with the monarch who reigned in a country founded under the auspices of God. "Portugal, therefore, owes its foundation to a special intervention of God and has, therefore, a specifically religious purpose". ${ }^{20}$

The translation of the document done by Friar Manoel de Sá reinforces the hypothesis that the City of Paraíba was already established, but not yet built. In ecclesiastical Latin, the words "build" and "found" are used in different ways. The first relates directly to a physical building; for this, we use the verb aedifico. For founding, meaning the act of creating or establishing something, distancing from the sense of physical construction, the use of the verb fundo is more common. Friar Manoel de Sá was a renowned religious man, famous for his studies; therefore, it is feasible to think that the Carmelite knew the difference between the verbs and aedifico and fundo, translating them with the correct meaning. If this hypothesis is true, the City of Paraíba was already established before 1580, but it was not yet built. ${ }^{21}$

\footnotetext{
${ }^{19}$ Evaldo Cabral de Mello, O nome e o sangue: uma parábola genealógica no Pernambuco colonial, São Paulo, Companhia das Letras, 2009, p. 238.

${ }^{20}$ Luís Palacin, Vieira e a visão trágica do Barroco, São Paulo, Hucitec, 1986, p. 36.

${ }^{21}$ Such statements are sustained by: Leo F. Stelten, Dictionary of ecclesiastical Latin: with an appendix of Latin expressions defined and clarified, Peabody, MA, Hendrickson, 2011; Francisco Torrinha, Dicionário Latino Português, 8. ed., Porto, Reunidos, [s.d.].
} 
When it is not possible to consult the original document, a historian must consider as evidence the small details that the documentation misses sometimes. In Sumário das Armadas, a document that narrates the conquest of Paraíba River, it is very clear that the masculine definite article "o" is used when the text refers to the river, and the feminine definite article "a" is used when it refers to the captaincy: "Pois as outras varzeas que ha entre Pernambuco e $a$ Parahiba e fazem ao longo dos rios que entra essas duas capitanias mais pegadas ao Parahiba[...]" (author's emphasis). ${ }^{22}$ Following the same logic, which is quite possible, given the temporal proximity between the documents (Sumário das Armadas was written between 1585 and 1587), the small series of letters of 1581 by the King about Frutuoso Barbosa and his fleet has the same syntactic structure, referring to "a" Paraíba (feminine), and not "o" Paraíba (masculine): "No que toca a madeyra do Brasil e ida do Frutuoso Barbosa povoar $a$ Parayba[...]”(author's emphasis $)^{23}$; "Frutuoso Barbosa que ya povoar $a$ Parayba nas partes do Brasil arribou com muita gente nessa" (author's emphasis) ${ }^{24}$. In the two remaining letters, the King refers to Frutuoso Barbosa as the "capitão da gente da povoação da Parahiba das partes do Brasil"25; "capitão da gente da povoação da Parahiba das partes do Brasil que ora mando com o dito cargo as ditas partes". ${ }^{26}$ It is necessary to investigate what post would that be, if the word "povoação" refers to a population nucleus, as I believe is more logical, since people are referred to by the word "gente", or to the human element - those who would live in captaincy of Paraiba -, which results in a redundancy of spelling.

In his Diálogos chronológicos, históricos, panegíricos, ascéticos sobre os frutos principaes e felizes progressos da ordem do Carmo Calçado em Portugal, Friar Miguel de Azevedo writes: "The Cardinal D. Henrique wanted to found Paraíba, wrote to the superior of Carmel and suggested that he sent him religious men of Science and Conscience to exercise the sacred ministry in the lands of that new establishment". ${ }^{27}$ In other words, the desire to found Paraíba existed; however, one should be very careful with this information because the manuscript is from the second half of the 18th century and its information comes from other secondary sources. While pointing to the idea that there was a legal fiction that the Captaincy of Paraíba was already created, at least from 1581 onwards, it is not possible to say that with certainty. However, these data raise doubts about the official founding date of Paraiba as August 5, 1585.

\footnotetext{
22"Because the other wetlands that are located between Pernambuco and Parahiba and exist along the rivers entering these two captaincies closer to the Parahiba [...]". Anônimo, Sumario das Armadas que si fizerão e guerras que se derão na conquista do Rio Parahiba escripta e feito por mandado do muito reverendo Padre em Christo o padre Cristóvão de Ganvia visitador da Companhia de Jesus de toda a Provincia do Brasil. Available from: <http://www.carlamaryoliveira.pro.br/1585 sumario das armadas.html>. Accessed on: March 29, 2013.

${ }^{23}$ "Regarding the wood from Brazil and the trip of Frutuoso Barbosa to populate the Parayba". Palácio Nacional da Ajuda (PNA), Cota: 49-x-4, fl. 264 v.

${ }^{24}$ Frutuoso Barbosa, who is already populating the Parayba in the areas of Brazil, arrived with a lot of people there". Ibidem, fl. 338.

${ }^{25}{ }^{2} \mathrm{C}$ Captain of the people of the village of Parahiba in the areas of Brazil". Idem, Cota: 49-x-1, fl. 343.

${ }^{26 " C a p t a i n}$ of the people of the village of Parahiba in the areas of Brazil that I am sending now to such areas with the mentioned post". Ibidem, fl. 344.

${ }^{27}$ Academia de Ciências de Lisboa, Cota: Ms. 86.
} 
The letter states that the Cardinal D. Henrique himself would have asked the Lisbon Convent to send missionaries to the enterprise of building the City of Paraíba. The carmelites who were sent there were not only friars, but also ordained clergymen, that is, able to hold masses and administer sacraments even where there was already a diocese, ${ }^{28}$ which were essential attributions in a land where there were almost no religious men. To be able to fulfill their missionary role, they needed a building where they could found a convent house, establishing their modus vivendi.

In the 16th century, it was not necessary to go very far to accomplish the indoctrination of natives that inhabited the vicinity of settlements. Pioneers in the missionary experience in Portuguese America, the Jesuits were already developing a system of settlements, instead of movable missions, which showed little result as the Indians returned to their habits as soon as the missionaries left the villages.

Seeking to adapt to these Indians, "without faith, without law, without king", the Jesuits of Brazil promoted the experience of establishing the mission in the village. The establishing process implied a transformation of the original missionary ideal, which thought the mission as an experience of itinerancy and poverty. By settling with the Indians and taking over their spiritual orientation, the missionary resembled a priest. [...] The settling of the missionary among the Indians also gave him indeed a political status of their administrator. He was the one who organized the work of the Indians, particularly for the benefit of the Company, and assured their political submission to the colonial power through embarrassment and physical punishment. ${ }^{29}$

However, this system required a large number of religious persons, who should live in the villages together with the Indians, keeping them under surveillance. The insufficient number of friars and the large number of natives to be catechized justify the widespread use of moveable missions that lasted until the 18th century as a way to assist in the evangelization of the Indians. However, before settling down at some village, these four religious figures needed to expand the Order of Our Lady of Mount Carmel in America, recruiting novices and providing good services to local society, the monarch, and God.

The letter from Friar João Cayado did not rule out the possibility of the carmelites settling elsewhere and mentioned the Captaincy of Pernambuco as a possible place where they could found a convent. The friars should accept any place that was offered to them or where they were useful in the service of the Church and, therefore, the Portuguese State. With this possibility, the superior freed the friars of the obligation to participate in the war of the conquest of Paraíba River, making the armada of Frutuoso an excuse and a means of transportation for the first Carmelite friars to Portuguese America.

\footnotetext{
${ }^{28}$ The papal bull Omnimoda, from 1522, authorized the regular clergy to administer the sacraments and celebrate mass in the Indies, in regions where there were no dioceses, a prerogative that did not apply to the four carmelites because they were also ordained clergymen.

${ }^{29}$ Charlotte de Castelnau-L’Estoile, Operários de uma vinha estéril: os jesuítas e a conversão dos índios no Brasil: 1580-1620, translated by Ilka Stern Cohen, Bauru, Edusc, 2006, p. 531
} 
The carmelites would not reach the Paraíba River in 1580. When the fleet arrived in Olinda, the friars settled in the village and gave up the journey of conquest. The inhabitants offered them a hermitage to care for, and the carmelites chose not to risk whatever little they had. Unwilling to exchange the certain for the doubtful, they chose to remain in the Captaincy of Pernambuco, not moving forward with the expedition of Frutuoso Barbosa, which also failed in the intent of conquering Paraíba River. The only condition put to the friars for the donation of the hermitage was that they maintained the invocation of the small temple of Saint Antônio de Pádua. This is the reason why the Carmelite Church of Olinda was devoted to a Franciscan saint, contradicting the custom of honoring a character related to the Order.

\section{In the 16th century, it was not necessary to go very far to accomplish the indoctrination of natives that inhabited the vicinity of settlements}

Who were these religious persons who settled in Pernambuco? We know very little about their lives. Friar Domingos Freyre was a very well-liked religious figure within the convent of Lisbon, "of great virtue and letters, a distinguished preacher of that time [...]" ${ }^{30}$ Highlighting the fact that he was a man of letters and wise speaker emphasizes the role of oratory skills in converting and maintaining the faith. Besides, being a man of letters made him fit to teach grammar and Christian doctrine to the illiterate and to those who wanted to enter the Order, as long as they complied with the other necessary conditions. By sending lettered men, the superior made it possible to start the gathering of novices to the Order of Our Lady of Mount Carmel as soon as they landed in American lands. Friar Domingos Freire was also appointed vicar of the carmelites with full temporal and spiritual powers. In other words, he was responsible for the construction of monasteries, their earnings, and everything related with material issues, but also for providing spiritual guidance to the other religious fellows that accompanied him, as well as the ones that entered the Order henceforth. For this purpose, Friar João Cayado gave him full power to act on his behalf, "as if we were there". ${ }^{1}$

This delegation of powers shows that the friars were aware of the slowness of communication between Brazil and Portugal. At this initial period, a series of practical decisions had to be made, since they could not wait for a correspondence process, as, for example, the decision about not accompanying Frutuoso in the expedition to Paraíba River, staying in Recife. Still, Friar Domingos Freire should inform the Convent of Lisbon that he would make interventions in the

${ }^{30}$ Frei Manoel de Sá, Memórias históricas da Ordem de Nossa Senhora do Carmo da Provincia de Portugal, Lisboa Oriental, Offycina Josep. Antonio da Silva, 1727, p. 33.

31/bidem, p. 35. 
process of establishing the Order in Portuguese America because it was the head monastery of the Province, to which all the houses should report.

According to the letters issued, the friars were apt to accept local men willing to become novices, but "the admission of Indians or Moors to the Order was forbidden". ${ }^{32}$ By accepting the people born in America, the Order opened the doors of its institution to local inhabitants, among whom there were mestizos, and many of them were children and relatives of local elites. In a not so distant future, the co-optation of these people to what the friars themselves called the "Carmelite religion" would mean obtaining favors and privileges more easily than other religious orders. Moreover, the carmelites already seemed to realize that the number of missionaries willing to live overseas was insufficient to meet the demand, hence the importance of indoctrinating people in the region to serve as vectors of multiplication for Christianity.

\section{The carmelites already seemed to realize that the number of missionaries willing to live overseas was insufficient to meet the demand}

The mendicant orders, among which is the Order of Our Lady of Mount Carmel, were authorized to do missionary work in the Indies by the mentioned bull Omnimoda, of March 9, 1522. When Friar João Cayado wrote the letter in 1580 , the carmelites had very little experience with missionary work, ${ }^{33}$ after all, it was a mendicant order, where ministry was secondary in comparison to contemplation.

Although it is a "mixed" Order (contemplative-active), the contemplative life prevails, which is the main purpose and reason for existing. Everything is organized according to the principality: the silence, the solitude, the austerity of life, the poverty etc. The apostolate is secondary, to the extent that it does not destroy the contemplative nature; but also necessary, almost as a requirement of the contemplative mood. ${ }^{34}$

Until the 16th century, members of the Order of Our Lady of Mount Carmel should stick to contemplation in their convents. They could celebrate mass and

\footnotetext{
32Balbino Velasco Bayón, História da Ordem do Carmo em Portugal, Lisboa, Paulinas, 2001, p. 185.

${ }^{33}$ There have been some attempts to deploy missions in the Indies before 1580, by sending friars to Yucatán, Cartagena (it is assumed that it is Carthage and not Cartagena de Indias) and Nova Granada. However, none of these attempts has resulted in a missionary project, because convents were not established in these locations. The Calced Order was banned in the 16th century from catechizing in Spanish America because of these ill-fated experiences. About these ephemeral experiences, see: Joaquín Smet, Los carmelitas: historia de la Orden Del Carmen, las reformas. Personas, literatura, arte, 1563-1750, Tomo III, Madrid, Biblioteca de Autores Cristianos, 1991.

${ }^{34}$ Daniel de Pablo Maroto, Historia de la espiritualidad cristiana, 2 ed., Madrid, Editorial de Espiritualidad, [s.d.], p. 182.
} 
administer the sacraments if they were ordained clergymen. While the primary aim of the Jesuits was to establish a missionary project, the carmelites did not have a history of militancy. It was the context of overseas expansion that led the carmelites to rethink their modus vivendi, incorporating the mission as part of their attributions. ${ }^{35}$

The overseas expansion leveraged the Company of Jesus, along with its militant ideal, to the frontline of the struggle of the Catholic Church to universalize Catholicism. The arrival of the Europeans in America ushered the beginning of an intense dispute in the regular clergy for the leadership in establishing missions in the four corners of the Earth. To survive in this new world that expanded, the religious orders sought to actively participate in this process of globalization, trying to meet the demands that grew as the Church was losing space in Europe for the Protestant Reformation.

The 16th century is the century of reform, of the major rupture, of the schism, of the seamless robe torn in two. And here as well as there, the Christians are the ones who oppose, no doubt, but Christians that reciprocally exclude themselves [of] Christianity. Since then, this old notion of Christendom applied as a unit to all Western populations professing Christianity is no longer possible. Christendom? It is torn. The Pope's Christianity is no longer the same as Luther's, Calvin's Christianity is no longer the same as Ignatius of Loyola's. One can no longer use the same word, the word Christendom, to group, to gather men who, precisely in Christian field, divorce. ${ }^{36}$

It was necessary to adapt the practice of regular clergy to the needs that arose in this new context; that was the reason why the Calced carmelites embraced the ideal of militant indoctrination of the world.

For the religious orders in Portuguese America, the apostolate, transmuted in missionary work, acquired a new status because of the thousands of souls there.

The discovery of America revealed later a true theological traumatism. Was it possible that so many men were condemned? And were the Indians really men? Some doubted that until the moment when Paul III responded affirmatively in his bull Sublimis Deus, of $1537 .{ }^{37}$

The bull stated that Indians had souls, being susceptible to indoctrination. Admitting that these Indians had some faith was part of the perspective that the missionary had of the native. Maria Cristina Pompa explains well:

\footnotetext{
${ }^{35}$ To justify themselves, the carmelites appealed to the figure of St. Bertoldo, a former crusader who was considered the first superior of the carmelites when the Order reappeared in the end of the 11th century, and to the Aelian foundation myth, which placed the prophet Elijah as direct founder of Carmel, extolling his figure as mystical-militant character. On this subject, see: André Cabral Honor, O verbo mais-que-perfeito: uma análise alegórica da cultura histórica carmelita na América portuguesa, Belo Horizonte, Fino Traço, 2013. ${ }^{36}$ Lucien Febvre, A Europa: gênese de uma civilização, Bauru, Edusc, 2004, p. 181.

${ }^{37}$ George Minois, História dos infernos, translated by Serafim Ferreira, Lisboa, Teorema, 1997, p. 300.
} 
The philosophical need of assigning the Indians beliefs, even if vague or erroneous, followed a cultural requirement of "reading" the other and translating it on your own terms, and, on the other hand, translate the "I" to the other. For this, it was necessary to construct a language of mediation. The primary code of reading and interpreting reality, including the anthropological otherness, was still the religious one in the early modern age. It comprised all others: moral, political, philosophical (remember the juxtaposition of faith, law and king). In other words, any social manifestation of alterity by the conquest was read a sub specie religionis, and translated in the religious language. ${ }^{38}$

Converting these people was central for the Church in order to compensate for the loss of believers to the Protestant reforms that disseminated in Europe. The religious men who set out on the journey to convert infidels were imbued not only with the "charity toward the neighbor", because they would not save just the souls of indigenous peoples, but also their own: "the purpose of the company is not solely to deal, in God's grace, with the salvation and perfection of their own souls, but, in the same grace, to strive immensely helping in the salvation and perfection of the neighbor".39

\section{While the primary aim of the Jesuits was to establish a missionary project, the carmelites did not have a history of militancy}

The redemption of the spirit through the conversion of the other, which is the base of Jesuit catechesis, mobilized the activist action and was used as a guideline by other orders in Portuguese America, with the carmelites among them.

This expansionism embodied features that were not part of the previous experience of Christians and of the Augustinian vision, by transforming all those outside the jurisdiction of the Church and the Pope in infidels and enemies to be converted or defeated. The idea of a Holy War did not belong to primitive Christianity, but to Islam, justified even by philosophers of the stature of Alfarabi. The Christianity of the early centuries valued, significantly, the martyrdom, the death without resistance in the name of God. The resounding affirmation of "Christendom" brought the Muslim program to the life of Christian Europe, organizing the Crusades as a warrior testimony of faith and a charismatic experience of death, tremendously powerful factors for community unification and assertion of papal authority. This expansionist, intolerant and aggressive spirit had particular impact in Iberia, the European frontier separating Christians and Muslims. ${ }^{40}$

\footnotetext{
${ }^{38}$ Maria Cristina Pompa, Religião como tradução: missionários, Tupi e "Tapuia" no Brasil colonial. Tese de doutorado, Universidade Estadual de Campinas, Campinas, 2001, p. 35. Available from: <http://www. bibliotecadigital.unicamp.br/document/?code=vtls000220275>. Accessed on: September 6, 2014.

${ }^{39}$ Ignácio de Loyola, Constituições da Companhia de Jesus e normas complementares, São Paulo, Loyola, 2004, p. 46.

${ }^{40}$ Rubem Barboza Filho, Tradição e artifício: Iberismo e Barroco na formação americana, Belo Horizonte, Editora da UFMG; Rio de Janeiro, IUPERJ, 2000, p. 163
} 
The concept of salvation of the missionary's soul through the conversion of the other was present within the Order of Our Lady of Mount Carmel since the beginning of its missionary project in Portuguese America. At the end of the letter written by Friar João Cayado, the author states that the sending of the four Carmelite friars would be useful not only for the salvation of the converted souls but also because the friars would "achieve a grand prize of charity". In other words, through the conversion of the "other", the "I" would be saved.

For the Iberian, Catholic and 17th-century Tridentine doctrine, life was a dream and the world was a theater, because the truth was outside the world, in God. And so, everything was a figure and image of God and a result of Creation. It was all a dream and drama of the Creation and the Creator. The First Cause of the world, God the Creator, also pointed to the Final Cause, God the Judge. The Creation, origin of everything, in which the human was made with an immortal soul, the reason of free will, pointed necessarily to its end, the Final Judgment, when those who condemned the soul by using reason and free will for error, succumbing to misleading pleasures of the flesh, would be separated from those who would be saved because they made the choice, rationally and freely, to refrain from the desires of the body and to control the passions of the soul. Human history would be the path from the Creation to the Final Judgment. God gave mankind a grace: to complete His project, the fate of the world and of the Creation through free will. It was up to humans, made secondary causes of Creation, to follow this desire, directing the will with good understanding and memory of the good laws and good examples, in order to choose the correctness among the errors. ${ }^{41}$

On the basis of considerations mentioned earlier, we can see the impact that the creation of the Company of Jesus had on Christianity, especially on the regular clergy. The Jesuits' idea of salvation was based on the conversion of the other; only through co-optation of souls for the Christian universe, the friar of the Company could save himself.

The expressed purpose of the Company is to save the soul of its members, and the salvation of the neighbor' soul is the means to that end. Therefore, the task that consists precisely in working for the salvation of the soul of the neighbor is presented as the means to achieve that end. Immediately, there is a strong connection between the salvation of the members of the Company and the salvation of the neighbor; it is the same "divine grace" that supports the two projects, to attain one's own salvation and to seek it for the others. The neighbor is placed as a means to achieve one's own salvation. ${ }^{42}$

This notion of salvation fitted perfectly into the context of overseas expansion, which revealed not only new lands and a circular world but also thousands of pagans who lived oblivious to the words of Christ. In order to legitimize the

4'Luís Filipe Lima; Ricardo Valle, "Introdução", In: Pedro Calderón de la Barca, A vida é sonho, translated by Renata Pallottini, São Paulo, Hedra, 2008, p. 16-17.

${ }^{42}$ Charlotte de Castelnau-L’Estoile, Operários de uma vinha estéril: os jesuítas e a conversão dos índios no Brasil: 1580-1620, translated by Ilka Stern Cohen, Bauru, Edusc, 2006, p. 95. 
possession of these lands, Portugal and Spain appealed to the Catholic Church, which recognized these two countries as owners of the new lands, validating the conquest through papal bulls. In return, the Spanish and Portuguese people should save these pagans, bringing Catholicism to them. The newly formed Company of Jesus took the lead in this process, with its activist notion of regular clergy, an idea that was almost concurrently copied by other religious orders that disseminated overseas.

The guidelines set out in the letter of Friar João
Cayado oriented carmelites throughout the period
during which Portugal owned a part of America

Thus, aware of these new winds that led the Catholic Church to the four corners of the world, the Order of Our Lady of Mount Carmel disembarked in Brazil with the mission to catechize the natives and evangelize the people. The guidelines set out in the letter from Friar João Cayado oriented carmelites throughout the period during which Portugal owned apart of America. Although they reinvented their practice in terms of the challenges presented to them, the reasons justifying the presence of the friars in the tropics underwent no major changes for over 200 years. They were here to evangelize souls, with special attention to natives. In 1687, the religious orders were demanded to catechize the natives: "Regal Letter of March 15, 1687, addressed to the governor João da Cunha Souto Maior, demands that the prelates of religious orders were notified to work in the propagation of the faith and the conservation of the Gentile". ${ }^{3}$ A royal letter of March 4, 1743 orders the expelling of religious orders that were not catechizing the Indians: "The monastic orders that do not engage in converting the gentile, which was the primary purpose of their institution, shall be declared extinct, and the convents will be transferred to those who were in fact fulfilling their duties".44

This situation would only change in the second half of the 18th century, when the Pombaline indigenous policy gradually transformed the settlements into villages. The same reasons that brought the carmelites to the overseas lands in the 16th century were also part of the reasons that explain their decay from the end of the 18th century onward. Suppressing the indigenous indoctrination, opting for a secular administration, the predilection for the secular clergy at the expense of the regular one in the celebration of Catholic rituals, the increase in the number of dioceses and the untying of Brazil to Portugal - all of these reasons combined with a Roman policy of suppressing religious orders made the presence of the members of the order in America almost obsolete.

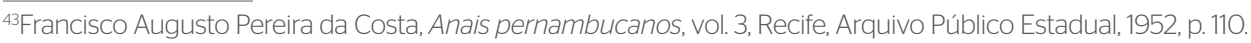
${ }^{44}$ João Manuel Pereira da Silva, História da fundação do império brasileiro, Tomo I, Paris, Garnier, 1864, p. 167. 
After the severe blow suffered during the reign of D. José I (1750-1777), the regular clergy managed to slow the pace of this process of decay during the rule of D. Maria I (1777-1799), because she was an extremely devout Queen, who financed the construction and renovation of churches. However, there was no renewal of the role to be played by members of the regular clergy in Portuguese America. With the rise of D. João VI (1799-1826) to the Portuguese throne, the policy of suppressing religious orders in Portugal and its dominions continued. Unable to restructure its purposes, the carmelites faded until they almost disappeared. It was only with the reinvention of the missionary role in the 20th century that the Calced Order of Our Lady of Mount Carmel would thrive again, imbued with the need to restore the bond between society and regular clergy that had been broken. 